\title{
Severe repetitive exercise and haematological status
}

\author{
J. H. RosS \\ M.C., M.D., F.R.C.P. \\ E. C. ATTwood \\ B.Sc., M.Sc., F.R.S.C., C.Chem.
}

County Hospital, Hereford HRI 2ER

\begin{abstract}
Summary
The effects of severe repetitive exercise on certain haematological measurements were studied. Decreases in haematocrit and haemoglobin (13\% in one group of participants) took place during the first 2 weeks but not the third week of increasingly severe exertion and the reasons for this are discussed. Haemolysis probably plays only a small part and plasma volume expansion is likely to be the main cause of this phenomenon. It is suggested that there is no stimulus for the haemoglobin concentration to be increased to match the increased plasma volume as tissue oxygen tension is maintained satisfactorily.
\end{abstract}

KEY WORDS: anaemia, haemolysis, plasma volume.

\section{Introduction}

Measurements of haematocrit (HCT) were included in a study of the changes in serum myoglobin and certain muscle enzymes in groups of young men taking part in a severe training course lasting 3 weeks (Ross et al., 1983). It was thought that increases in HCT might help to assess dehydration and the consistent finding of decreases was unexpected. There have been few previous observations of this phenomenon and the mechanism has not been clearly defined.

Exercise of shorter duration has been studied. Pugh (1969) found an increase in blood volume (mean of 3.9\%) and reduction of haematocrit (mean $2 \cdot 1 \%$ ) in six hill-walkers walking 28 miles in $8-10 \mathrm{hr}$. Williams et al. (1979) studied five subjects walking vigorously on Welsh hills for 7 consecutive days and found a decrease in packed cell volume (PCV) reaching a maximum of $11 \%$ by day 5 . They concluded from water and sodium balance studies that an increase in plasma volume was responsible. They dismissed the possibility of erythrocyte haemolysis and considered reduced erythrocyte production or inhibition of release or sequestration unlikely. The same group (Milledge et al., 1982) made a later study of five subjects before, during and after hill-walking for 5 days. They confirmed the fall in PCV and increase in plasma volume with retention of sodium and marked increases in plasma renin activity and aldosterone levels.

In contrast, Lindemann et al. (1978) studying 44 Norwegian army recruits during 4- and 5-day combat courses found falls in PCV (15-20\%), haemoglobin (18-20\%) and in haptoglobin, with a rise in bilirubin, and considered that their data indicated haemolysis during the severe exercise. The combat courses took place in a forest with a soft surface and there was only minor body trauma, so that "march haemoglobinuria" was thought unlikely. Plasma volume increase was not considered to have taken place but direct measurements were not made. Dressendorfer, Wade and Amsterdam (1981) studied 12 runners during a 20-day, 312-mile road race and considered inhibition of erythropoiesis a possible explanation for falls in haemoglobin, PCV and red cell count, but came to no definite conclusion.

There have been other less well documented references to such findings and low PCV among soldiers in basic combat training has been said to be a "widespread problem" and a cause for blood-donation rejection (Bell and Cowan, 1978). Similar findings among athletes in training have led to the expression "sports anaemia" (Yoshimura, 1970). Hunding, Jordal and Paulev (1981) found iron deficiency in $56 \%$ of joggers and competition runners with very low haptoglobin levels; some runners had free haemoglobin in their plasma. They considered iron therapy necessary. Brotherhood, Brozovic and Pugh (1975), who also noted lower serum iron levels in athletes than in non-athletes, found that oral iron made no difference; they found blood volume and total body haemoglobin to be higher in the athletes than the non-athletes.

We made a more detailed study, after our initial observation of HCT decrease, on a subsequent training course and the results are of interest as the effects of exercise of increasing severity were observed for a longer period than in the studies which have been quoted above. 


\section{Methods}

There was difficulty in arranging an ideal protocol as the volunteers were concerned primarily with completing successfully their severe competitive ordeal and it was not possible to subject them to frequent venesection or to collect urine specimens.

The volunteers were men aged 20 to 35 years who had prepared for the course with about 2 weeks of walks, runs, swimming and gymnasium exercises, and could therefore be assumed to be healthy but not at the peak of physical training. The majority had been travelling during the $24 \mathrm{hr}$ preceding the first venesection and were therefore in a resting state. Table 1 shows their programme, the points at which blood was taken and the number of volunteers remaining at each venesection.

Twenty millilitres of blood were taken from each volunteer at the times indicated in Table 1. Five millilitres were put in an EDTA bottle and the remainder was allowed to clot. Sera from venesections $\mathrm{A}, \mathrm{B}$ and $\mathrm{C}$ were separated within $\mathrm{l} \mathrm{hr}$ of collection. The EDTA specimens from these venesections went into a refrigerator at $4^{\circ} \mathrm{C}$ within an hour of collection. Specimens from venesection $D$ were taken over $6 \mathrm{hr}$ and were all at $4^{\circ} \mathrm{C}$ within $7 \mathrm{hr}$. All specimens were examined within $24 \mathrm{hr}$.

Leucocyte count (WBC), erythrocyte count (RBC), haemoglobin $(\mathrm{Hb})$, haematocrit (HCT), mean cell volume (MCV), mean cell haemoglobin $(\mathrm{MCH})$ and mean cell haemoglobin concentration (MCHC) were measured in a Coulter Counter Model S (Coulter Electronics Limited, Harpenden, Hertfordshire). There was no allowance for trapped plasma in the haematocrit measurement. Serum iron was determined colorimetrically using ferrozine on a Technicon Autoanalyser I. Serum transferrin and haptoglobin were assayed by immunoturbidimetry with a Centrifichem 500 using antisera supplied by Atlantic Antibodies (American Hospital Supply (U.K.) Limited, Didcot, Oxfordshire). Serum albumin and total protein were determined using a Technicon SMA Plus Autoanalyser.

\section{Results}

The results are shown in Table 2. Means and standard deviations were calculated both for the total numbers of subjects venesected on each occasion (the decreasing numbers being due to the fallout during the strenuous exercise) and separately for those 21 subjects who survived the whole course. Both sets of figures are shown and there were no differences of statistical significance between "totals" and "survivors". Significance values were calculated by the Student's $t$-test.

The changes in haematocrit and haemoglobin are also shown in Figs. 1 and 2 (Group I) which, in
TABLE 1. Summary of exercise programme

\begin{tabular}{|c|c|c|c|}
\hline Day & $\begin{array}{l}\text { Number of } \\
\text { subjects }\end{array}$ & Venesection & Preceding activity \\
\hline 1 & 91 & A & In evening after arrival \\
\hline 4 & 66 & B & $\begin{array}{l}4 \mathrm{hr} \text { after } 15 \mathrm{~km} \text { run } \\
\text { and } 2 \text { days of running } \\
\text { and gymnasium work }\end{array}$ \\
\hline 18 & 45 & C & $\begin{array}{l}\text { On a rest day after } \\
\text { further } 10 \text { days of } \\
\text { exercise (up to } 25 \mathrm{~km} \text { of } \\
\text { mountain walking) and } 3 \\
\text { interspersed rest days }\end{array}$ \\
\hline 24 & 21 & D & $\begin{array}{c}\text { Immediately after } \\
\text { completion of } 64 \mathrm{~km} \text { severe } \\
\text { mountain walk, carrying } \\
35 \mathrm{~kg} \text { and after } 5 \text { preceding } \\
\text { days of similar severe } \\
\text { activity ( } 176 \mathrm{~km} \text { in } 6 \text { days) }\end{array}$ \\
\hline
\end{tabular}

addition, illustrate the findings from a separate group (Group II, consisting of 33 men initially, with 15 survivors) who joined the course a week later than Group I and exercised more severely in the 3 days between their venesections $A$ and $B$. Their initial resting values for $\mathrm{Hb}$ and $\mathrm{HCT}$ were significantly lower $(P<0.001)$ than those for Group I; they had probably taken more exercise during the weeks before the course, a factor which was thought to explain similar differences in the initial serum muscle enzyme estimations between the two groups (Ross $e t$ al., 1983).

Both groups showed significant and equivalent falls in $\mathrm{Hb}$ and $\mathrm{HCT}$ with their initial exercising (A-B). The $\mathrm{Hb}$ and HCT of both groups were identical at the rest point $C$ and there were no further changes during the final very severe 6 days' exercise.

Serum iron only fell significantly during the final 6 days. Haptoglobin fell with the initial exercising, rose again by the rest point $\mathrm{C}$ and fell during the final 6 days.

Correlation coefficients between haematological measurements and serum albumin levels were calculated for paired changes in individuals and are shown in Table 3.

\section{Discussion}

Williams et al. (1979) and Milledge et al. (1982) clearly showed that plasma volume expansion took place during repetitive exercise but haemolysis, as suggested by Lindemann et al. (1978), can be expected also to play a part in decreasing $\mathrm{Hb}$ and HCT. The fall in haptoglobin which we observed indicated that haemolysis had occurred, but this was unlikely to have been the whole explanation. The marrow of healthy young men could be expected to maintain haemoglobin concentration at initial levels 
TABLE 2. Haematological data (Mean \pm s.d.)

\begin{tabular}{|c|c|c|c|c|c|c|c|}
\hline & \multicolumn{2}{|c|}{ (A) on arrival } & \multicolumn{2}{|c|}{$\begin{array}{l}\text { (B) After } 3 \text { days' } \\
\text { moderate exercise }\end{array}$} & \multicolumn{2}{|c|}{$\begin{array}{l}\text { (C) Rest period } \\
\text { after } 18 \text { days }\end{array}$} & \multirow[t]{2}{*}{$\begin{array}{c}\text { (D) After } 6 \text { final } \\
\text { days } \\
\text { of severe exercise }\end{array}$} \\
\hline & Total & Survivors & Total & Survivors & Total & Survivors & \\
\hline $\begin{array}{l}n \\
\text { WBC }\left(10^{9} / 1\right) \\
\text { RBC }\left(10^{12} / 1\right) \\
\text { Hb }(\mathrm{g} / \mathrm{dl}) \\
\text { HCT } \\
\text { MCV (f) } \\
\text { MCH (pg) } \\
\text { MCHC (g/dl) } \\
\text { Iron }(\mu \mathrm{mol} / 1) \\
\text { Transferrin }(\mathrm{g} / \mathrm{l}) \\
\text { Haptoglobin }(\mathrm{g} / \mathrm{l})\end{array}$ & $\begin{array}{c}91 \\
8.2 \pm 1 \cdot 6 \\
5 \cdot 21 \pm 0.24 \\
15.9 \pm 0.7 \\
0.457 \pm 0.019 \\
88.9 \pm 2.9 \\
30 \cdot 4 \pm 1 \cdot 1 \\
34.5 \pm 0.6 \\
18.9 \pm 5 \cdot 8 \\
3.26 \pm 0.41 \\
1.05 \pm 0.45\end{array}$ & $\begin{array}{c}21 \\
7 \cdot 6 \pm 1 \cdot 6 \\
5 \cdot 12 \pm 0 \cdot 22 \\
15 \cdot 6 \pm 0 \cdot 6 \\
0 \cdot 451 \pm 0 \cdot 016 \\
89 \cdot 0 \pm 2 \cdot 7 \\
30 \cdot 3 \pm 1 \cdot 1 \\
34 \cdot 2 \pm 0 \cdot 4 \\
22 \cdot 1 \pm 6 \cdot 8 \\
3 \cdot 18 \pm 0 \cdot 30 \\
0 \cdot 99 \pm 0 \cdot 54\end{array}$ & $\begin{array}{c}66 \\
11 \cdot 6 \pm 2 \cdot 1 \\
4 \cdot 96 \pm 0 \cdot 26 \\
15 \cdot 0 \pm 2 \cdot 1 \\
0 \cdot 440 \pm 0 \cdot 024 \\
89 \cdot 4 \pm 2 \cdot 7^{*} \\
30 \cdot 5 \pm 1 \cdot 0^{*} \\
34 \cdot 3 \pm 0 \cdot 6^{*} \\
16 \cdot 7 \pm 4 \cdot 0^{*} \\
3 \cdot 23 \pm 0 \cdot 32^{*} \\
0 \cdot 38 \pm 0 \cdot 35\end{array}$ & $\begin{array}{c}21 \\
10 \cdot 4 \pm 1 \cdot 5 \\
4 \cdot 83 \pm 0 \cdot 24 \\
14 \cdot 87 \pm 0 \cdot 78 \\
0 \cdot 430 \pm 0 \cdot 020 \\
89 \cdot 7 \pm 2 \cdot 1 \\
30 \cdot 6 \pm 0 \cdot 9 \\
34 \cdot 3 \pm 0 \cdot 7 \\
16 \cdot 9 \pm 3 \cdot 4 \\
3 \cdot 13 \pm 0 \cdot 22 \\
0 \cdot 37 \pm 0 \cdot 39\end{array}$ & $\begin{array}{c}45 \\
5 \cdot 7 \pm 1 \cdot 1 \\
4 \cdot 45 \pm 0 \cdot 23 \\
13 \cdot 6 \pm 0 \cdot 7 \\
0 \cdot 397 \pm 0 \cdot 019 \\
88 \cdot 9 \pm 3 \cdot 2^{*} \dagger \\
30 \cdot 5 \pm 1 \cdot 2^{*} \dagger \\
34 \cdot 1 \pm 0 \cdot 6 \dagger \phi \\
15 \cdot 5 \pm 5 \cdot 0 \dagger \\
3 \cdot 10 \pm 0 \cdot 408 \\
0 \cdot 89 \pm 0 \cdot 42^{*}\end{array}$ & $\begin{array}{c}\quad 21 \\
5 \cdot 6 \pm 1 \cdot 4 \\
4 \cdot 43 \pm 0 \cdot 24 \\
13 \cdot 5 \pm 0 \cdot 7 \\
0 \cdot 395 \pm 0 \cdot 018 \\
89 \cdot 0 \pm 3 \cdot 1 \\
30 \cdot 5 \pm 1 \cdot 1 \\
34 \cdot 1 \pm 0.5 \\
15 \cdot 5 \pm 5 \cdot 5 \\
3 \cdot 19 \pm 0 \cdot 33 \\
0.91 \pm 0 \cdot 38\end{array}$ & $\begin{array}{c}21 \\
12 \cdot 3 \pm 3 \cdot 4 \dagger \\
4 \cdot 43 \pm 0 \cdot 22 \ddagger \\
13 \cdot 5 \pm 0 \cdot 7 \ddagger \\
0 \cdot 392 \pm 0 \cdot 016 \ddagger \\
88 \cdot 2 \pm 3 \cdot 0^{*} \ddagger \ddagger \\
30 \cdot 4 \pm 1 \cdot 3^{*} \dagger \ddagger \\
34 \cdot 3 \pm 0 \cdot 6^{*} \dagger \ddagger \\
8 \cdot 3 \pm 3 \cdot 8 \\
3 \cdot 00 \pm 0 \cdot 24 \ddagger \phi \\
0 \cdot 44 \pm 0 \cdot 38 \dagger\end{array}$ \\
\hline
\end{tabular}

Significance values for "total" columns: $P<0.001$ except where indicated by following symbols: *No significant difference from A to B, A to $\mathrm{C}$, A to $\mathrm{D}$; †No significant difference from $\mathrm{B}$ to $\mathrm{C}, \mathrm{B}$ to $\mathrm{D}$; $\ddagger$ No significant difference from $\mathrm{C}$ to $\mathrm{D} ; \mathrm{\S P}=<0.005>0.001$ from $\mathrm{A}$ to $\mathrm{C}, \mathrm{A}$ to $D, B$ to D; There were no differences in statistical significance between the "Total" and "Survivors" figures.

TABLE 3. Correlations between changes in Hb, RBC, HCT and changes in serum albumin (see Table 1 for times of venesection)

\begin{tabular}{cccc}
\hline & Group I (A-B) & Group II (A-B) & Groups I \& II (C-D) \\
\hline Hb v. albumin & 0.714 & 0.760 & 0.600 \\
HCT v. albumin & 0.649 & 0.759 & 0.576 \\
RBC v. albumin & 0.601 & 0.729 & 0.589 \\
Albumin v. total protein & 0.756 & 0.813 & 0.823 \\
\hline
\end{tabular}

Correlation coefficients calculated for paired changes in individuals. All correlations $P<0.001$.

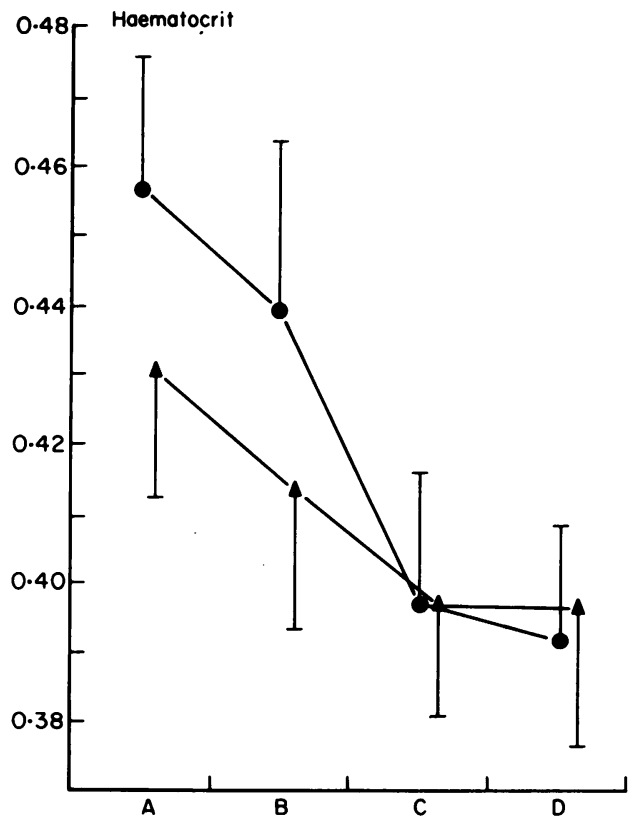

FIG. 1. Haematocrit. (๑) Group I; (ム) Group II. (A) on arrival, before course; (B) after 3 days exercise; (C) rest period, after 18 days; (D) after 6 final days of severe exercise.

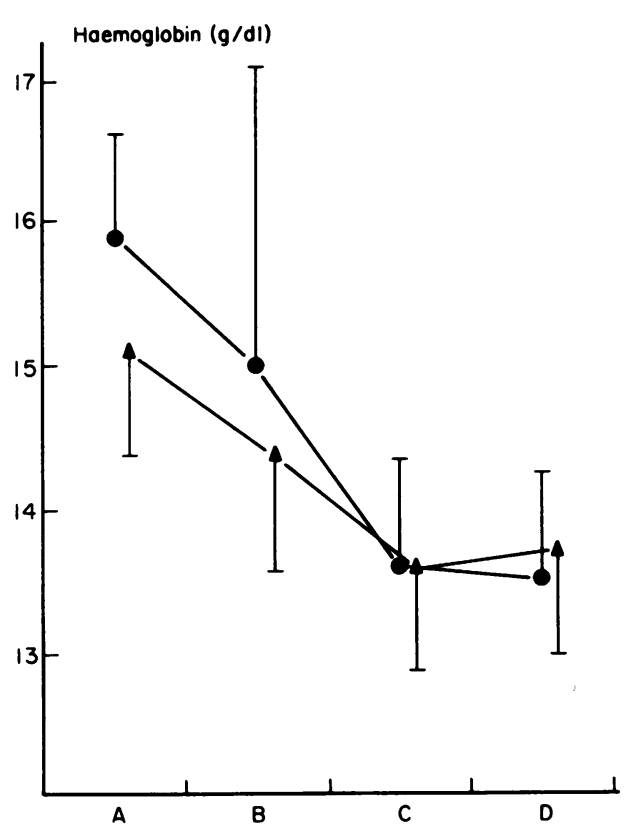

FIG. 2. Haemoglobin g/dl. (๑) Group I; ( $)$ Group II. (A) on arrival, before course; (B) after 3 days exercise; (C) rest period, after 18 days; (D) after 6 final days of severe exercise. 
in the face of a loss of about $1 \%$ per day. If haemolysis had been the whole explanation in our subjects it might have been expected to manifest itself further during the final severe exercising, although a diminishing tendency to haemolyse could be explained by Davidson's (1969) suggestion that the more fragile aged red cells are replaced during the early stages of exercise by a younger, more resistant, population. A pattern, similar to ours, of diminishing decreases in Hb and PCV can in fact be seen in the data from the marathon runners observed by Dressendorfer, Wade and Amsterdam (1981).

The correlations which we observed between $\mathrm{Hb}$, RBC and HCT and changes in serum albumin (Table 3) could be indirect evidence of a common mechanism, plasma volume expansion, affecting all these factors, if alterations in protein synthesis can be discounted. It is likely that a persisting increase in plasma volume without an equivalent increase in red cells or maintenance of haemoglobin concentration was responsible for our findings. If tissue oxygen tension is maintained satisfactorily during repetitive exercise such as we studied then erythropoiesis would not be stimulated to increase the circulating haemoglobin concentration to "normal". The observations of Brotherhood et al. (1975) support this possibility. They found mean total body haemoglobin to be $20 \%$ higher in athletes than non-athletes and suggested that haemoglobin concentration and blood volume are independently controlled.

A dilution phenomenon cannot be responsible for the fall in iron which only occurred significantly during the final severe exercising when haemoglobin and haematocrit did not decrease and perhaps uptake by marrow and muscle was responsible. The Norwegian recruits also showed a fall in serum iron during the latter halves of combat courses (Lindemann et al., 1978). Deprivation of food which has been shown to lead to a fall in iron (Palmblad, 1976) may be relevant to our findings.

Determination of the precise parts played by plasma volume expansion and haemolysis in lowering haemoglobin concentration during severe exer- cise could be of importance to those concerned with the training of athletes and military recruits and a more detailed study is being made.

\section{Acknowledgment}

We are most grateful to the volunteers for their co-operation, to the West Midlands Regional Research Committee for a grant, to Mrs Pat Rossi and Mrs Jennifer Dunn for secretarial help, to the Hereford Laboratory staff and to many venesectors for help with specimens.

\section{References}

BeLl, J. \& CowAN, G.S.M. (1978) Low blood haematocrits in male Army volunteers during basic training. New England Journal of Medicine, 299, 491.

BRoTherhood, J., BRozovic, P. \& PUGH, L.G.C. (1975) Haematological status of middle- and long-distance runners. Clinical Science and Molecular Medicine, 48, 139.

DAVIDSON, R.J.L. (1969) March or exertional hemoglobinuria. Seminars in Hematology, 6, 150.

DRESSENDORFER, R.H., WADE, C.E. \& AMSTERDAM, E.A. (1981) Development of pseudoanemia in marathon runners during a 20 day road race. Journal of the American Medical Association, 246, 1215.

Hunding, A., JoRdal, R. \& Paulev, P.E. (1981) Runners' anemia and iron deficiency. Acta Medica Scandinavica, 209, 315.

LindemanN, R., Ekanger, R., OPSTAD, P.K., Nummestad, M. \& LJOSLAND, R. (1978) Hematological changes in normal men during prolonged severe exercise. American Corrective Therapy Journal, 32, 107.

MilledGe, J.S., Bryson, E.I., Catley, D.M., Hesp, R., LufF, N., MINTY, B.D., Older, M.W.J., PaYNe, N.N., WARD, M.P. \& WITHEY, W.R. (1982) Sodium balance, fluid homeostasis and the renin-aldosterone system during the prolonged exercise of hill walking. Clinical Science, 62, 595.

Palmblad, J. (1976) Fasting (acute energy deprivation) in man: effect on polymorphonuclear granulocyte functions, plasma iron and serum transferrin. Scandinavian Journal of Haematology, 17, 217.

PUGH, L.G.C.E. (1969) Blood volume changes in outdoor exercise of 8-10 hour duration. Journal of Physiology, 200, 345.

Ross, J.H., ATTWOOD, E.C., ATKIN, G.E. \& VillaR, R.N. (1983) A study of the effects of severe repetitive exercise on serum myoglobin, creatine kinase, transaminases and lactate dehydrogenase. Quarterly Journal of Medicine, NS52, 268.

Williams, E.S., WARD, M.P., Milledge, J.S., Withey, W.R., OLDER, M.W.J. \& FoRSLING, M.L. (1979) Effect of the exercise of seven consecutive days' hill-walking on fluid homeostatis. Clinical Science, 56, 305.

YoshimuRA, H. (1970) Anemia during physical training (Sports Anemia). Nutrition Reviews, 28, 251. 